\title{
SPINOZA ON CEREMONIAL OBSERVANCES AND THE MORAL FUNCTION OF RELIGION*
}

\author{
WILLEM LEMMENS
}

\begin{abstract}
"Piety and religion - O everlasting God - take the form of of ridiculous mysteries; (...)"
\end{abstract} Spinoza, Tractatus Theologico-Politicus, Preface

\section{Spinoza on piety and ceremonial observances}

In Chapter 5 of the Tractatus Theologico-Politicus Spinoza contends that "it is quite indisputable that ceremonial observances contribute nothing to blessedness, and that those specified in the Old Testament, and indeed the whole Mosaic Law, were relevant only to the Hebrew state, and consequently to no more than temporal prosperity" (TTP, V, 440). ${ }^{1}$ Spinoza further specifies that the same thesis could be applied to Christian rites, "namely, baptism, the Lord's Supper, festivals, public prayers, and all the other ceremonies that are, and always have been, common to all Christendom (...)" Whether these practices and rites were instituted by Christ or His Apostles is even open to doubt, according to Spinoza. They were in any case only instituted as "external signs of a universal Church, not as conducing to blessedness". Therefore, practices and ceremonial observances do not contain "an intrinsic holiness" (TTP, V, 440).

The thesis defended here plays a crucial role throughout the TTP. For Spinoza religious practices - such as rites, prayers and all sorts of ceremonial observances - form no intrinsic part of the life of virtue and do not lead directly

\footnotetext{
* This paper was originally delivered as a talk at the international workshop on Spinoza's Tractatus Theologico-Politicus, organised by the Netherlands Organisation for Scientific Research, University of Leiden, Department of Philosophy (May 20, 2008). I thank Eric Schliesser for inviting me and the other participants for their stimulating comments. Suggestions by Ursula Goldenbaum, Herman De Dijn and Stephen Nadler on an earlier version of this text helped me a lot. I am especially indebted to an anonymous referee of Bijdragen for some clarifications and improvements.

1 All references to the Tractatus Theologico Politicus and the Ethics are to the Shirley edition: Benedict de Spinoza, Complete Works, With the Translations of Samuel Shirley, Edited by Michel L. Morgan, Hackett Publishing Company, Indianapolis/Cambridge, 2002.
} 
to moral perfection. With reference to the ancient Hebrew State of the Old Testament, Spinoza acknowledges that the sense of devotion and obligation towards the religious practices required by the ceremonial law (as laid down in the Torah) upheld the establishment of the political community under Moses. He further contends that the observance of the laws of the "Patriarchs or their successors" is pleasing to God insofar it vouchsafes the continuing prosperity and material advantages of the Hebrew people (TTP, III, 418). But obedience towards the ceremonial law is for Spinoza clearly not identical with true piety, which consists in a life in accordance with the moral law of charity and justice. Only this second sort of obedience or obligation towards the Divine Law (Lex Divina) leads to salvation and blessedness. ${ }^{2}$ The Divine Law, after all, is the law of pure rational reason, which all humans in principle can know and pay tribute to: the "true way of life" consists in obedience towards this Law, to which all sorts of ceremonial religious laws remain always external, and necessarily so (TTP, V, 435).

For Spinoza the distinction between 'mere' observance of the (ceremonial) law and a life according to the moral law is crucial. The true 'moral life' is a pious life, a life in which piety and virtue coincide and become almost identical. For Spinoza obedience to the Divine Law forms the core of moral excellence: piety put in practice, so to say. A life in accordance with the Divine Law leads to happiness. As such, piety is an universal virtue for all humans and is therefore attainable by everyone, irrespective of ones religious tradition. In contrast, obedience towards a contingent set of practices or ceremonies (e.g. the ceremonial law for the Hebrews) should be neatly distinguished from piety. If piety as such would be intrinsically related to ceremonial observances, then true virtue and happiness would depend on a contingent cultural tradition. A life according to the Hebrew or Christian faith, or whatever other religious tradition, would then ipso facto - by virtue of its relation to this tradition -

\footnotetext{
2 Spinoza mentions the 'Divine Law' (lex divina) or the 'natural Divine Law' (Lex divina naturalis) as opposed tot the revealed Divine Law (Lex Divina revelata) which depends on the contingent history of a specific religious tradition or nation, such as 'Mosaic law'. Cf.: “(...) lege Mosis non magis tenenatur, quam antequam eorum societas, \& Respublica inciperit; dum enim inter alias Nationes, ante exitum ex Aegypto vixerunt, nullas leges peculiares habuerunt, nec ullo, nisi naturali jure, $\&$ sine dubio, etiam jure reipublica, in qua vivebant, quatenus legi divinae naturali non repugnabat, tenebantur." ("[...] Jews are no more bound by the Mosaic Law than they were before their political state came into being. For while they were living among other nations before the exodus from Egypt, they had no special laws to themselves; they were bound by no law other than the natural law, and doubtless the law of the state in which they dwelt, insofar as that was not opposed to the natural Divine Law." [TTP, V, p. 437]) Latin text: Spinoza, Opera, Vol. III, ed. Carl Gebhardt, Heidelberg, C. Winters, 1927, p. 72.
} 
become a blessed life. God however, so Spinoza defends, is equally "gracious and merciful to all men", irrespective of the religious tradition to which they belong (TTP, III, 420).

From his naturalistic hermeneutics of the religious phenomenon - if I may thus qualify the guiding idea behind the TTP - Spinoza's critical investigation of the ceremonial law may appear obvious and easy to interpret. In the TTP Spinoza defends not only the independence of philosophy (or reason) from theology, but also intends to separate out the genuine, 'true' religion from superstition. In other words, next to the philosophical unmasking of religious faith as a product of the passions and imagination, the TTP aims at a better understanding of the practical role religion could play in the life of humans. For in the TTP Spinoza clearly defends that the core of religion lies in piety or obedience to the law of charity and justice. Religion - when healthy or 'true' in the sense of genuine and authentic - thus functions as a vehicle for the practice of virtue and the attainment of happiness. In Spinoza's view, pious faith should be distinguished from superstition. This last one is exactly the opposite of faith, because it alienates common people from the salvation true religion or the life of virtue offers.

The identification of true religion with piety or moral obedience in the TTP diverges at first sight hardly from the definition of religion offered in the Ethics (Book IV P37). Here, religion is conceived of as a practical disposition which emerges from adequate knowledge of God. ${ }^{3}$ Adequate knowledge of God is in Spinoza's view not purely theoretical since it functions as a moral guidance for the philosopher. Spinoza contends: "whatever we desire and do of which we are the cause insofar as we have an idea of God, i.e. insofar as we know God, I refer to Religion (religio). The desire to do good which derives from our living by the guidance of reason, I call Piety (Pietas)." ${ }^{4}$ Religion thus conceived is not only intrinsically related to the practice of philosophical thinking, but is also strongly interwoven with friendship and honour - so Spinoza specifies. The virtues of friendship and honor (honestas) establish the community of the wise: also for the wise, true piety is the fruit of a specific form of communal life or religio. In Ethics, Book V Spinoza further point out that for the wise (the true philosopher) salvation is reached through the intellectual love

\footnotetext{
3 For more on the practical significance of religion thus conceived in the Ethics see: Herman De Dijn, 'Spinoza and Religious Emotions', in Willem Lemmens, Walter Van Herck (eds.), Religious Emotions. Some Philosophical Explorations, Cambridge Scholars Publishing, pp. 107-108.

4 Ethics, IV P37 S1.
} 
of God (amor intellectualis Dei) which goes together with a sustained contentment of mind (animi acquiescentia), which is in fact a form of glory. ${ }^{5}$

But it becomes apparent now that there remains a gap between the true philosophical religion of the Ethics and the genuine religion of the TTP, identified as the truthful life of piety and obedience. The first, so Spinoza firmly contends, is only attainable by the few wise: the second is necessarily interwoven with a historical tradition and a contingent socio-political setting - such as he Hebrew State or the churches in Western Christianity. The first consists in a life according to reason, the second remains strongly dependent on custom (a religious tradition) and imagination. This opposition places Spinoza's hermeneutics of popular and historical religion(s) for a sort of dilemma. For, on the one hand, religion understood as the pious faith of common people (or 'popular religion') should be opposed to the true philosophical religion; on the other hand, insofar historical religions enable and foster a life of true virtue and piety, they contain the germs of salvation and a specific modality of blessedness. In the TTP Spinoza gives pride of place to the idea that the life of the prophets bears testimony to the fact that true piety can also be reached by not fully rational humans, who live according to superstitious beliefs and practices of a particular tradition.

Indeed, the moral life of the masses in Hebrew culture, insofar as it was not based on reason but on the imagination and the passions, required a religious tradition to flourish. Thus, as the history of the Jewish people bears witness to, a specific religious- political society became the soil for the establishment of a genuine moral community: the Law of Moses and the prophets was a necessary precondition for the flourishing of virtue and happiness within this community. But if this is the case, the question becomes whether ceremonial observances cannot also be considered as part and parcel of the true moral life, be it of not fully rational people, living within the bounds of a traditional religious community. ${ }^{6}$

This question is in the light of Spinoza's philosophy more urgent and puzzling then one at first sight could be willing to admit. For if the way of the

\footnotetext{
5 According to De Dijn the 'gloria' or self-glorification of the wise stems from the intellectual awareness of "the truth about oneself and about one's real relation to God". It is a sort of perfection of blessedness, which cannot be attained by the common people, who only know blessedness through moral obedience. Cf.: De Dijn, o.c., p. 116.

${ }^{6}$ In correspondence Ursula Goldenbaum has mentioned to me that in her view Moses Mendelssohn was directly influenced by his lecture of Spinoza's TTP when he defended the possibility of a Jewish Enlightenment which at the same time remained faithful to the ceremonial law of the Bible.
} 
sage - the truly rational life of the philosopher - is hard to go and therefore necessarily the privilege of a happy few, it seems unavoidable that the masses will always remain in one way or another captives of specific religious traditions and superstitions. ${ }^{7}$

Spinoza's critical stance towards the Jewish ceremonial law as being of merely historical and external significance then brings to the forefront the question how a traditional religion could preserve its authentic moral function and keep at the same time safe from the devastating influences of superstition and religious zeal. Is it not essential for historical religions to rely on practices and ceremonies which foster and shape in one way or another the sense of obedience towards the Divine Law? Perhaps popular religions, insofar they form a precondition of piety among the masses, play after all a much more positive role than Spinoza's critical and rather negative appreciation of ceremonial observances in TTP, $V$ suggests. In the following, I would like to elucidate how Spinoza's conception of the possibility of a healthy, genuine religion affects his evaluation of the ceremonial law and popular religion in the TTP.

\section{Towards a moral critique of the ceremonial law}

The ceremonial law of the Hebrews and later on of Christianity exemplifies a historical contingent fact, which derives nonetheless of a universal feature of human nature: the need for a conventional morality, based on a common life in a historical community under the guidance of a moral-spiritual authority and a collectively shared narrative. In monotheistic religions this narrative has the form of the revelation of Gods Word. Mainly referring to the Judeo-Christian tradition throughout the TTP, Spinoza leaves place for the idea that this political function of religion could be fulfilled also in a polytheistic tradition. In any case, the ceremonial law derives always its meaning from a historical narrative: it is, in more than one sense, therefore also constitutive of a concrete religious tradition - as the history of Moses and the Hebrews bear witness to. Spinoza's critique of the ceremonial law forms then part and parcel of his hermeneutics of superstition. For superstition emerges clearly whenever the symbols, rites and practices required by ceremonial life become disentangled from their proper moral-spiritual function. Through the concise explanation in the Preface of the TTP it becomes clear that this disentanglement gives undue significance and value to the merely temporal ordinances, ceremonies and

7 See also: Susan James, Spinoza on Supersition. Coming to Terms with Fear, Mededelingen van het Spinozahuis 88, Damon, 2006. 
practices of whatever historical religion. In superstition the favor of the Deity towards the faithful is considered to depend on the worship expressed through sacrifices and rituals and in the strict observance of creeds and dogma's laid down in the sacred narratives (the holy book) of a specific religion.

Superstition is according to Spinoza among the most powerful forces in human life, to which all men are by nature liable (TTP, Preface, 389). It is also clear for Spinoza that this perversion of the proper moral function of ceremonial observances is almost unavoidable, given the ambivalent character of their origin. Superstitious observances arise from the passions, most importantly from fear and hope. In the grip of these emotions the superstitious mind seeks in an obsessive way to alleviate his anxiety by the ritual obedience to a strongly anthropomorphic Deity, which is at the same time admired and feared. ${ }^{8}$ The obedience to the ceremonies and creeds of the religious tradition takes the place of the purity of heart and the moral life plan which should be the sign of a truly religious way of life. Through superstition, humans become not attached to the doing of 'good works' and the cultivation of love for ones neighbour and God, but to the obedience towards the ceremonial law as such. ${ }^{9}$

In TTP, V Spinoza firmly criticizes Maimonides who considered the life according to the scriptural authority (the Law of Moses) a conditio sine qua non for blessedness. ${ }^{10}$ Quoting R. Joseph in his Kebod Elochim, Spinoza denounces the implication that from this perspective Aristotle may be able to derive virtue from reason, but is unable to reach true salvation or blessedness (TTP, V, 443). Superstition relies, in short, on the idea that through the adherence to outer signs, sacrifices and ceremonial observances required by the ordinances of institutionalised religion, one will be privileged by God in receiving the means and powers to control ones existence and receive consolation for life's misery and even be compensated for the sadness caused thereby. This credulity, required for upholding this sense of election, is fostered by the

\footnotetext{
${ }^{8}$ Some century after Spinoza Hume will give an almost identical genealogy of superstition and false religion. Cf. David Hume, The Natural History of Religion, ed. by Tom Beauchamp, The Clarendon Edition of the Works of David Hume, Clarendon Press, 2007, Section 1-3.

${ }^{9}$ For more on the relation between emotions, religion and superstition in Spinoza, cf. De Dijn, o.c.; Susan James, art. cit.

${ }^{10}$ Maimonides is quoted saying: "Every man who takes to heart the seven commandments and diligently follows them belongs to the pious of nations and is heir to the world to come; that is to say, if he takes them to heart and follows them because God has ordained them in his Law, and has revealed to us through Moses that they were formerly ordained for the sons of Noah. But if he follows them through the guidance of reason, he is not a dweller among the pious nor among the wise of nations" (TTP, V, 443).
} 
imagination. The more one sanctifies all sorts of practices and rituals required by the ceremonial law, the more the anthropomorphic images of God and the whole sacred order become object of worship. And in turn, the slavish attitudes towards the ministers and teachers of ones own religion become a sort of second nature, fortified by the inculcation of the doctrine of faith.

Thus superstition feeds on religious fanaticism and will become under specific conditions a major source of political turmoil. For the political strife between religious factions has its source precisely in this claim for doctrinal Truth, which is nothing else than a means to gain dominion over the minds of men. Sarcastically, Spinoza characterises in the preface of the TTP the solution of the Islam to avoid further sedition caused by such doctrinal quarrels: the Turks - i.e. the Islam - invested their religion with such "pomp and ceremony" that "it can sustain any shock and constantly evoke the deepest reverence in all its worshippers". They thus succeeded to consider "even discussion of religion to be sinful" and eradicated any sense of critical judgment on the side of the individual believer: no place for sound reason is left, even for "the capacity to doubt" (TTP, Preface, 389).

Against this background, Spinoza's plaidoyer for a sincere, almost pietistic religion, with moral practice and purity of heart as its kernel, cannot surprise us. As a matter of fact, in TTP, V Spinoza affirms that it is perfectly conceivable to live a pious - i.e. truly religious - life without exercising "any outward rites of religion" or identifying with the doctrines and dogma's of whatever established religion.

This idea is illustrated with the example of the Dutch representatives of the East India Company living in Japan. Bound to abstain from their rites because the Christian religion was forbidden, these merchants could in principle live none the less "in a state of blessedness" (TTP, V, 440). Spinoza further specifies as follows his contention: "(...) if a man is absolutely ignorant of the Scriptures, and none the les has right opinions and a true plan of life, he is absolutely blessed and truly possesses in himself the spirit of Christ" (TTP, V, 441). In the same vein, Spinoza earlier in the TTP refers to Paul who preaches that the faith in Christ save the faithful from the bondage of the law: "(...) so that no longer would they act righteously from the law's command but from the unwavering resolution of the heart". And Spinoza adds, significantly: "Thus Paul's teaching concides exactly with ours" (TTP, III, 423). Spinoza considers the true religion of the philosophical sage - the life of reason - to be in tune with the kernel of the revealed religion of both Jews and Christians " (...) for not only reason itself, but the assertions of the prophet and the Apostles clearly proclaim that God's eternal Word and covenant and true religion are divinely inscribed 
in men's hearts - that is, in men's minds - and that is the true handwriting of God which he has sealed with his own seal, this seal being the idea of himself, the image of his own divinity, as it were" (TTP, XII, 504).

From Spinoza's biography we know about his sympathy for the non-ceremonial religion of the Collegiants, with its focus on the inner life and the moral purity of heart. ${ }^{11}$ Nonetheless, among contemporaries Spinoza's critical attitude in the TTP towards the ceremonial law of especially the Hebrews, but also by extension Christendom, caused indignation. According to the French Huguenot Minister Jean-Baptiste Stoupe in his La Religion des Hollandais (1673) this attitude was a clear indication of the true intentions of "ce Spinoza, Juif renegat", namely to spread "Atheisme, le libertinage \& la liberté de toutes les Religions". ${ }^{12}$ The officer of the Prince of Condé may have had political intentions whith suggesting that Spinoza's libertinage showed how Holland in the 17th century became a religious madhouse - as Popkin suggests. Stoupe argued, for example, that the sort of Christian Marranism' of the Dutch merchants in Japan had nothing to do with blessedness, but just was a clear sign of their mercantile opportunism. ${ }^{13}$

Whatever may be the historical truth about this, it remains worthwhile to ask how exactly Spinoza conceived of the possibility of a pure, non-ceremonial religion - given exactly his naturalistic hermeneutics of religion throughout the TTP. For after all, critical as he may be about the historical religions of his time, Spinoza also clearly points out how the genius of the Hebrew faith and the preaching of the Christian Apostles fostered the sense of the Divine Law and made at certain specific times in history a true moral life possible for common people.

Without doubt, then, there exists a certain tension between Spinoza's contention that true blessedness and a sincere life of piety can be conceived of independently of any ceremonial law, and his broader conception of human nature and the origins of religion. Indeed, Spinoza's account of these origins makes it hardly conceivable that a life of moral obedience and piety could really flourish independently of any institutionalised or revealed religion. Within the temporal order of a living community a ceremonial law or a set of rites and ceremonial practices, as incarnation of a concrete religious tradition, seems

\footnotetext{
${ }^{11}$ Stephen Nadler, Spinoza. A Life, Cambridge University Press, 1999, pp. 139-141; 167-70. Cf. also: Richard H. Popkin, 'The First Published Discussion of a Central Theme in Spinoza's Tractatus', in Philosophia, vol. 17, $\mathrm{n}^{\mathrm{o}}$ 2, 1987, pp. 101-109.

12 Stoupe (1673) cited in Popkin, art. cit., p. 101.

13 Popkin, art.cit., p. 104.
} 
absolutely required, despite the suggestion to the contrary implied in Spinoza's critical attitude towards the ceremonial law of the Hebrews.

\section{Positive aspects of ceremonial observances in Hebrew religion}

When Spinoza turns to the evaluation of the role of prophets - especially Moses - in the establishment of the Hebrew religion, a more constructive approach and appreciation of the moral function of religious traditions becomes apparent. Convincingly, Spinoza depicts prophets as men of extraordinary imagination and moral practice. These exceptional figures of Hebrew history, so we learn throughout the TTP, not only tried to inculcate in the hearts of the common people the obedience to the ceremonial law, but at the same time "devoted themselves to piety with especial constancy" (TTP, I, 403). The founders and defenders of the Hebrew faith were thus not only morally exemplary figures who obeyed the Divine Law in a non-cognitive, highly passionate manner: the effectiveness of their prophecies was intrinsically interwoven with their own attachment to the ceremonial law and their propagation of it.

For the Hebrew people, so Spinoza acknowledges referring to the Biblical narrative of the Patriarchs, the observance of the ritual sacrifices was "the principle means of inducing reverence" (TTP, V, 437). In the same vein, the genius of Moses consisted in introducing a religion which made the people do their duty "from devotion rather than fear" (TTP, V, 439). It may be the case, as Spinoza contends, that Moses' sole care, like that of all prophets, was in the first place to teach moral doctrines distinguished of the laws of the state as such; it is none the less also the case that the inculcation of devotion in the hearts of the people required exactly the propagation of this temporal law, with its particular ordinances and ceremonial observances in order "to preserve and strengthen the Hebrew state" (TTP, V, 438).

Spinoza clearly indicates how this sense of devotion flourishes through the cultivation and transformation of the very same passions that lie at the origin of superstition. The fear and anxiety of the people are by Moses' guidance and foresight transformed into a stabilising identification with the Divine covenant. Thus giving hope to the community and inculcating the sense of duty towards God and one's neighbour, the Hebrews learned to obey in a steadfast manner the Divine Law of Justice and Charity. Spinoza sounds not very friendly when he characterises the almost childish understanding of the Hebrews under Moses, but these observations could equally be applied to human nature writ large: "Men, women, children, all are equally capable of obedience by command, but not of wisdom by command" (TTP, XIII, 512). But it is exactly this 
lack of natural reason and wisdom, which makes it necessary to work on the imagination and passions of the common people to establish in their hearts the sense of obedience and devotion. And in order to obtain that goal, the reliance on a 'law written down' is unavoidable.

This law - symbolised for the Hebrews in Moses' tables of stone (TTP, XII, 506) - has, as Spinoza contends, a merely conventional character. But in the temporal order in which it has to function, it cannot so easily be disentangled from the moral message it bears and the spiritual objective it wants to realise. For the common people living under Moses, devotion and ceremonial observance are intrinsically interwoven. Without the propagation of the concrete law, and its symbolisation in rites, sacrifices, rules of purity, etc... there would be no clear sense of obedience possible, no understanding of the true moral message given voice by the prophets, because there would be no soil, so to say, for the true moral intentions - and thus blessedness or salvation - to flourish in the heart of the common people.

This brings us by an element of human nature on which the effectiveness of the ceremonial law depends in spreading its moral message and fostering true piety in the heart of the believers: the remarkable force of the imagination. ${ }^{14}$ As Spinoza contends:

"Imagination by itself, unlike every clear and distinct idea, does not of its own nature carry certainty with it. In order that we may attain certainty of what we imagine, there has to be something in addition to imagination, namely reasoning. Hence it follows that prophecy cannot of itself carry certainty, because, as I have shown, it depended solely on the imagination. So the prophets were not assured of God's revelation through the revelation itself, but through a sign" (TTP, II, 405).

Pointing out the role of the imagination on the side of the prophets in the first place, Spinoza indirectly brings here also under attention that his message's 'moral certitude' (which by Spinoza is sharply distinguished from Truth or 'mathematical certitude') rely on the mechanism of collective imaginative projection, so crucial in superstition. ${ }^{15}$ In other words, the inventive power of

${ }^{14}$ De Dijn also highlights the positive role the imagination receives in the TTP in fostering positive religious emotions, cf. De Dijn, 'Spinoza and revealed religion', in Studia Spinozana, 11, 1995, pp. 39-52. Cf. also: Paul Juffermans, Drie perspectieven op religie in het denken van Spinoza, Damon, 2003, pp. 340-344.

15 "Moreover, the certainty afforded by prophecy was not a mathematical certainty, bu only a moral certainty." (TTP, II, 405). The concept of certitudo moralis is also used by Descartes (it stems from Aristotle). In fact, the sort of moral 'certainty' Spinoza has in mind is a form of practical knowledge which depends on the imagination but transcends it in a way. It should be distinguished from pure mathemical knowledge insofar this last one depends on a priori intelligible pure ideas. 
the imagination, whereby a word or message - or for that sake also an object or place - becomes sacred and thus the symbolic incarnation of the revelation of Gods Law, in reality depends on a collective assent, whereby this object is 'baptised' so to say and recognised in its sacred status.

In what one could call the act of collective symbolisation the prophets word, supported by his inner intention and devotion, is recognised by the populace (or some wise men among them) as such a sign, thus establishing the certitude of the prophets message. On this 'fait social total' (Marcel Mauss) the establishment of a sacred order, so I would defend, depends. This reveals also the deep meaning of Spinoza's reference in the foregoing quotation to 'some extrinsic reason' which is required to make the certitude of prophecy effective. In the most literary sense of the word, the imagination has thus a revelatory force. Spinoza speaks about "God's revelation": but what is called "revelation' is in fact caused by wholly natural antecedents, namely the imagination and the passions of the members of a community or a specific group of wise and quasi-enlightened men within a specific community.

It would be wrong to suggest, as Spinoza seems to do when separating out intention or meaning and sign from each other - e.g. when he distinguishes the externality of the ceremonial law from the blessedness of the pious mind of the prophet -, that the certainty and purity of his message could be conceived of independent of the sign. For as Spinoza acknowledges himself: the certitude of prophecy is based on three related conditions, each of which is necessary for the religious revelation to be effective and infuse the mind of the faithful with its creative power: (1) that the things revealed were imagined very vividly, affecting the prophets as if they saw these things (i.e. God's sign - WL) almost as real as when awake; (2) the presence of a sign; (3) that the mind of the prophet was given wholly to what was right and good. ${ }^{16}$

The constitutive force of symbolisation here at work is remarkable indeed. ${ }^{17}$ The three conditions mentioned establish, in a mutual supportive dialectic,

\footnotetext{
16 "Therefore the certainty of the prophets was based entirely on these three considerations: 1. That the things revealed were most vividly imagined, just as we are wont to be affected by objects in our waking hours. affecting the prophets in the same way as things seen when awake; 2 . The occurrence of a sign. 3. Lastly and most important, that the minds of the prophets were directed exclusively towards what was right and good." (TTP, II, 406).

17 The role of this symbolic practice is recognised by David Hume as constitutive for moral conventions such as the rules of property and promises in the sphere of justice. Hume explicitly makes a comparison between vulgar superstitions and the 'magic' whereby an object becomes recognised as property (cf. his Enquiry concerning the Principles of Morals, 3.36-37, ed. By Tom L. Beauchamp, The Clarendon Edition of the Works of David Hume, 1998). Thus, acording to Hume, useful
} 
the moral certainty of faith: the message of the prophet, interwoven with his word and gesture - say, his sanctifying of the table of stone on which the law is written down, or his ceremonial worship of the book in which the law is revealed -, and this all supported by his moral example recognised by all. One could even consider the symbolising act of an effective prophecy, based on the imagination and passions, as a real re-enactment of the original covenant on which the whole religious tradition of the Hebrew people was based. This original act, as it is described by Spinoza in Chapter XVII of the TTP, clearly is the product of a collective agreement, not based on rational certainty or adequate knowledge of the Natural Divine Law, but on the complex process of symbolisation whereby the collectivity of the Hebrew people, stirred by the example and imaginative word of Moses, created so to say ex nihilo the reality of its own covenant with God. ${ }^{18}$ Thus was established not only the Divine Law, but also the sacredness of the tables on which the Law was written down and the Ark of the Covenant, and, last but not least, the sense of obedience, required for a life of piety and salvation. And thus the passions of fear and anxiety were succesfully transformed, steered by the vivid collective imagination, into the attitude of collective devotion.

\section{From ceremonial law to piety}

One could wonder how this positive appreciation of the ceremonial law - or the symbolic order of a particular religion - fits with Spinoza's dismissive

social conventions also depend, for their effective establishment, on the imagination and passionate identifications of the collectivity, just as the establishment of a sacred order does within a religious tradition. In his Enquiry concerning Human Understanding, Hume observes: "We shadow out the objects of our faith, say they (the Roman Catholics), in sensible types and images, and render them more present to us by the immediate presence of these types, than is possible for us to do merely by an intellectual view and contemplation. Sensible objects have always a greater influence on the fancy than any other; and this influence they readily convey to those ideas to which they are related, and which they resemble" (Enquiry concerning Human Understanding, 5.16, Clarendon Edition of the Works of David Hume, 2000, pp. 42-43).

18 "Finding themselves thus placed in the state of nature, they hearkened to Moses, in whom they all placed the greatest confidence, and resolved to transfer their right not to any mortal man, but to God alone. Without much hesitation they all promised, equally and with one voice, to obey God absolutely in all his commands and to acknowledge no other law but that which he should proclaim as such by prophetic revelation. Now this promise, or transference of right to God, was made in the same way as we have previously conceived it to be made in the case of an ordinary community when men decide to surrender their natural right. For it was by express covenant and oath (Exod. Ch. 24 v. 7) that they surrendered their natural right and transferred it to God, which they did freely, not by forcible coercion or fear of threats" (TTP, XVII, 539). 
hermeneutics of superstition. He strongly suggests, so I tried to point out in this article, that the undue sanctification of the ceremonial law is a clear sign of superstition. Spinoza is adamant about this. In a comment on the alleged sacredness of Scripture, he claims:

\footnotetext{
"A thing is called sacred and divine when its purpose is to foster piety and religion, and it is sacred only for as long as men use it in a religious way. If men cease to be pious, the thing will likewise cease to be sacred; if it is devoted to impious uses, then that which before was sacred will become unclean and profane" (TTP, XII, 505).
}

And Spinoza further observes: "Thus it follows that nothing is sacred or profane or impure in an absolute sense apart from the mind, but only in relation to the mind."

Apparently, for Spinoza it should always be possible to isolate the pure intention of the religious mind and the sincere and pious attitudes of the faithful from the symbolic order (the ceremonial law) in which intention and attitude actually come to expression. However, in the context of the foregoing observation Spinoza makes clear that the relation between intention (meaning) and symbolic incarnation in relation to the sacredness of Scripture is more complex. It should be clear that the perversion of the reverence for the sacred object for example the Holy Book - can go in both directions. It could happen that the Bible, being the word of God, is worshipped in a superstitious manner, as is done by those who claim that to ignore the sacredness of the Scripture is as sinful as to ignore the Divine Law written in the heart. "In reply, I have to say," so comments Spinoza with scorn, "that such objectors are carrying their piety too far, and are turning religion into superstition; indeed, instead of God's Word they are beginning to worship likeness and images, that is, paper and ink". This attitude of negligence towards the real message and moral meaning of God's Word has often been shown by the Jews, so Spinoza contends, for example among the Sadducees, who exemplified the habit "to strive in defence of a law written on tablets" instead of living according to the law inscribed in their minds (TTP, XII, 504).

But Spinoza also points to another possibility. He admits that "some ungodly men who find religion a burden can assume from my views a licence to sin and, without any justification and merely to gratify their desires, can conclude there from that Scripture is at all points faulty and contaminated, and therefore has no authority". Spinoza has not much patience with this attitude. He considers it a clear indication of the fact that such men "are beyond help" and should be condemned as firmly as the superstitious minds who sanctify the sacredness of the Holy Book with superstitious zeal. Both attitudes are for Spinoza forms 
of moral failure: "All men, Jews and Gentiles alike, have always been the same, and in every age virtue has been exceedingly rare" (TTP, XII, 504). In other words, the sacredness of the Bible should be taken for granted as long as it supports and symbolically expresses the sense of devotion and the purity of heart of the faithful. Spinoza's recognition of the sacredness of the 'word of God' depends here, so it seems, upon the very moral certitude the prophets and Moses, and in the New Testament Christ, exemplified in and through the narrative of the Holy Book. No external legitimation is given for this recognition. For Spinoza it is impossible to assess from a purely external point of view where lies, within a historical religion, the distinction between superstition and sincere devotion. ${ }^{19}$

The condemnation of the excessive superstitious attitude, as well as of an impious attitude of profanation, depends therefore on an internal understanding and appreciation of the way the ceremonial law is exemplified in the character and the way of life of the true, pious believer. This internal understanding depends not on any scientific insight or rational knowledge of the philosopher, but emerges from the very practices of a religious tradition as such. This (moral) knowledge is exemplified, for example, in the life and teachings of the prophets.

Willem Lemmens (1963) is professor for Ethics and Modern Philosophy at the University of Antwerp. His major fields of research are: the history of modern moral philosophy, fundamental ethics and bio-ethics. He has published articles in various journals and chapters in books on a.o. Hume, Hobbes and Spinoza, but also on contemporary moral and political philosophers like Charles Taylor, Iris Murdoch, Alasdair MacIntyre and Martha Nussbaum and on bio-ethical issues. He is co-editor (with Walter Van Herck) of Religious Emotions. Some Philosophical Explorations, Cambridge Scholars Publishing, 2008.

Address: Prinsstraat 13, B-2000 Antwerpen.

${ }^{19}$ CF. Susan James, art. cit.. 